\title{
Analisis Pengaruh Efektivitas Dan Manfaat E-Commerce Terhadap Sikap Dan Perilaku Pengguna Dengan Menggunakan Metode TAM (Studi Kasus: UKM Kota Palembang)
}

\author{
Yulistia \\ Komputerisasi Akuntansi STMIK MDP Palembang \\ Yulistia@mdp.ac.id
}

\begin{abstract}
The appropriateuse of technology make us more good at utilizing it. Especially with online shopping provided by the business in building and deploying their business through a computer network. We know that many people who are busy with their work that make them do not have a lot of time to be able to spend time doing conventional business when they need it. Utilization of information and communication technology for the benefit of society and business especially Small and Medium Enterprises (SME), has been applied in various forms. One form of information technology application is E-Commerce system as the the use of information and communication technology to promote sales online.Along with the advancement of technologies, E-Commerce can be developed to improve the effectiveness and quality in sales and purchases. The E-Commerce system has a number of facilities such as online shopping, testimony, how to send, and so much more. This research describes the results of research on the extent of users attitudes and behavior, in this case is SME in Palembang, utilize information technology in the form of E-Commerce by using Theory Acceptance Model (TAM) method, so it can be known how far the effectiveness and benefits of E-Commerce system is in helping media sales and purchases online.
\end{abstract}

Keywords: E-Commerce, TAM model, Effectiveness, Online.

\begin{abstract}
Abstrak
Penggunaan teknologi yang tepat guna membuat kita lebih semakin mahir dalam memanfaatkannya. Terutama dengan belanja online yang disediakan oleh pebisnis dalam membangun dan menggelar bisnis mereka melalui jaringan komputer. Kita tahu bahwa banyak orang yang sibuk dengan pekerjaan mereka sehingga membuat mereka tidak punya banyak waktu untuk melakukan bisnis secara konvensional pada saat mereka membutuhkan. Pemanfaatan teknologi informasi dan komunikasi untuk kepentingan masyarakat dan bisnis khususnya Usaha Kecil Menengah (UKM) telah diterapkan dalam berbagai bentuk. Salah satu bentuk aplikasi pemanfaatan teknologi informasi tersebut adalah sistem E-Commerce yaitu penggunaan teknologi informasi dan komunikasi untuk mempromosikan penjualan online. Seiring dengan kemajuan teknologi, E-Commerce dapat dikembangkan untuk meningkatkan efektivitas dan kualitas penjualan dan pembelian. Sistem E-Commerce memiliki sejumlah fasilitas seperti belanja online, testimoni, cara kirim, dan masih banyak lagi. Penelitian ini menguraikan hasil penelitian mengenai sejauh mana sikap dan perilaku pengguna dalam hal ini adalah sektor UKM di Palembang, dalam memanfaatkan teknologi informasi dalam bentuk E-Commerce dengan menggunakan metode Theory Acceptance Model(TAM), sehingga bisa diketahui seberapa jauh keefektifan dan manfaat sistem E-Commerce dalam membantu sebagai media penjualan dan pembelian secara online.
\end{abstract}

Kata kunci: E-Commerce, Model TAM, Efektivitas, Online. 


\section{PENDAHULUAN}

Perkembangan ilmu pengetahuan dan teknologi khususnya teknologi informasi yang semakin pesat disegala bidang tidak dapat terelakan lagi. Teknologi informasi merupakan alat untuk mempermudah, mempercepat dalam melakukan pekerjaan. Seiring dengan kemajuan teknologi sekarang ini, penerapan E-Commerce menawarkan satu metode belanja secara langsung. Banyak keuntungan yang dapat diperoleh dengan penerapan metode E-Commerce seperti kita tidak perlu menyediakan waktu khusus untuk belanja dan tidak terbatas oleh jarak yang ada. Teknologi informasi yang paling banyak orang gunakan adalah internet. Dengan menggunakan internet orang dapat berkomunikasi dengan orang lain tanpa mengenal waktu dan jarak. Dengan penerapan internet ke dalam proses bisnis perusahaan, sehingga dapat menjangkau pengguna yang lebih luas dan meningkatkan keuntungan pada perusahaan tersebut. Oleh karena itu proses bisnis salah satunya yaitu pemasaran dengan menggunakan media online. Untuk dapat mengetahui sejauh mana pengaruh kepercayaan dan kemudahan dalam penggunaan media online yang biasa disebut dengan istilah E-Commerce. Perkembangan E-Commerce sekarang sudah merambah keseluruh daerah. Sehingga kita tidak perlu lagi untuk datang membeli barang tersebut dengan datang ketoko. Salah satu usaha yang dijalankan adalah usaha UKM dikota Palembang. UKM merupakan salah satu kreaktivitas masyarakat dengan melakukan transaksi penjualan. Peneliti ingin melihat sejauhmana manfaat website E-Commerce yang dilakukan oleh UKM untuk mengetahui sejauhmana manfaat E-Commerce tersebut untuk UKM yang ada, khususnya pada toko komputer yang ada di Palembang. Peneliti akan menganalisa besarnya pengaruh tersebut terhadap manfaat E-Commerce, khusunya pada sektor Usaha Kecil Menengah (UKM).

\subsection{Website E-comerce}

Sejak tahun 1965 sebagai salah satu alat bantu aktifitas bisnis perusahaan dalam bentuk ATM (Automatic Teller Machine) (Molla \& Licker 2001) [1]. Pengertian E-Commerce dapat dilihat dari tiga aspek yaitu perdagangan (commerce), fungsi bisnis dan kerjasama (collaboration). Berdasarkan ketiga aspek tersebut, E-Commerce dapat di definisikan sebagai aplikasi teknologi jejaring telekomunikasi (telecomunication network) untuk melakukan suatu transaksi bisnis, pertukaran informasi dan menjaga hubungan dengan konsumen sebelum, selama dan setelah proses pembelian (Costa 2001; Haag, Cummings \& Dawkins 1998; Post \& Anderson 2000; Zwass 1998) [2]. Sedangkan pengertian website adalah suatu kumpulan dari beberapa tampilan halaman dari file dan dokumen secara hypermedia melalui media komputer dan jejaring untuk mempermudah komunikasi dan aktifitas pelayanan bisnis selama 24 jam denga para konsumen dan rekanan bisnis (http://www.getnetwise.org; D"Angelo J little 1998; Hoffman \& Novak 1997) [3].

\subsection{E-Commerce}

Electronic Commerce (E-Commerce) adalah proses pembelian, penjualan atau pertukaran produk, jasa dan informasi melalui jaringan komputer. E-Commerce merupakan bagian dari ebusiness, dimana cakupan e-business lebih luas, tidak hanya sekedar perniagaan tetapi mencakup juga pengkolaborasian mitra bisnis, pelayanan nasabah, lowongan pekerjaan dll. Selain teknologi jaringan www, E-Commerce juga memerlukan teknologi basis data atau pangkalan data (database), e-surat atau surat elektronik (e-mail), dan bentuk teknologi non komputer yang lain seperti halnya sistem pengiriman barang, dan alat pembayaran untuk $E$ Commerce ini (Siregar, 2010) [4].

Menurut Rahmati (2009) [5] E-Commerce singkatan dari Electronic Commerce yang artinya sistem pemasaran secara atau dengan media elektronik. E-Commerce ini mencakup distribusi, penjualan, pembelian, marketing dan servis dari sebuah produk yang dilakukan dalam sebuah sistem elektronika seperti Internet atau bentuk jaringan komputer yang lain. 


\subsection{Sikap}

Sikap dapat dirumuskan sebagai kecenderungan untuk merespons (secara positif atau negatif) terhadap orang, obyek atau situasi tertentu. Sikap mengandung suatu penilaian emosional/afektif (senang, benci, sedih, dsb), disamping komponen kognitif (pengetahuan tentang obyek itu) serta aspek konatif (kecendrungan bertindak). Sedangkan pengetahuan lebih bersifat pengenalan suatu benda/hal secara obyektif. Selain bersifat positif atau negatif, sikap memiliki tingkat kedalaman yang berbeda-beda (sangat benci, agak benci, dsb). Sikap itu tidaklah sama dengan perilaku dan perilaku tidaklah selalu mencerminkan sikap seseorang, sebab seringkali terjadi bahwa seseorang memperlihatkan tindakanyang bertentangan dengan sikapnya. Sikap seseorang dapat berubah dengan diperolehnya tambahan informasi tentang obyek tersebut, melalui persuasi serta tekanan dari kelompok sosialnya (Sarwono, 1998) [6].

\subsection{Efektivitas}

Efektifitas adalah suatu ukuran yang menyatakan seberapa jauh target (kuantitas, kualitas dan waktu) telah tercapai. Dimana makin besar presentase target yang dicapai, makin tinggi efektifitasnya".(Hidayat, 1986) [7]

\subsection{Teori-teori Penerimaan Teknologi}

\subsubsection{Theory of Reasoned Action (TRA)}

Fishbein dan Ajzen pada tahun 1975 mencetuskan sebuah teori yaitu Theory of Reasoned Action (TRA) (Jogiyanto, 2007) [8]. Berdasarkan teori TRA, Fishbein dan Ajzen menyatakan bahwa perilaku seseorang dipengaruhi oleh kecenderungan perilaku orang tersebut. Model TRA ini dapat digambarkan seperti yang bisa dilihat pada Gambar 1 .

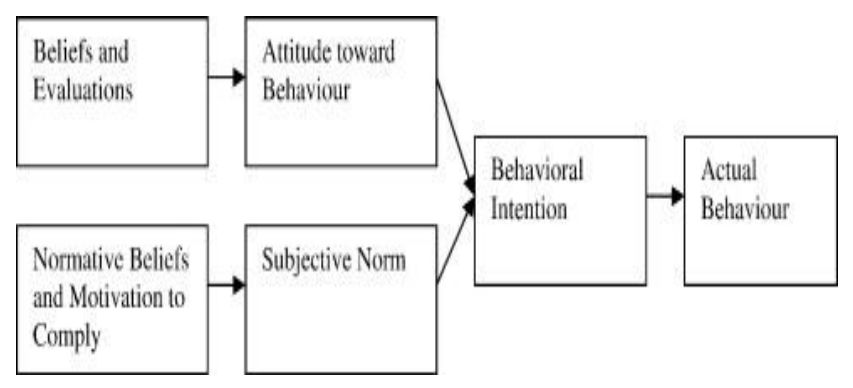

Gambar 1. Theory of Reasoned Action (TRA) (FishbeindanAjzen, 1975) [9]

\subsubsection{Theory of Planned Behaviour (TPB)}

Teori perilaku rencanaan (Theory of Planned Behaviour) merupakan pengembangan lebih lanjut dari Theory of Reasoned Action (TRA). Teori ini dikembangkan oleh Ajzen pada tahun 1988 (Jogiyanto, 2007) [8]. Terdapat satu perbedaan antara TRA dan TPB yaitu adanya Perceived Behavioural Control (PBC). PBC merefleksikan pengalaman masa lalu dan juga mengantisipasi halangan-halangan yang ada. Kriterianya yaitu semakin menarik sikap dan norma subyektif terhadap suatu perilaku, dan semakin besar PBC, semakin kuat minat seseorang untuk melakukan perilaku yang sedang dipertimbangkan. Berikut adalah gambaran mengenai Theory of Planned Behaviour (TPB). 


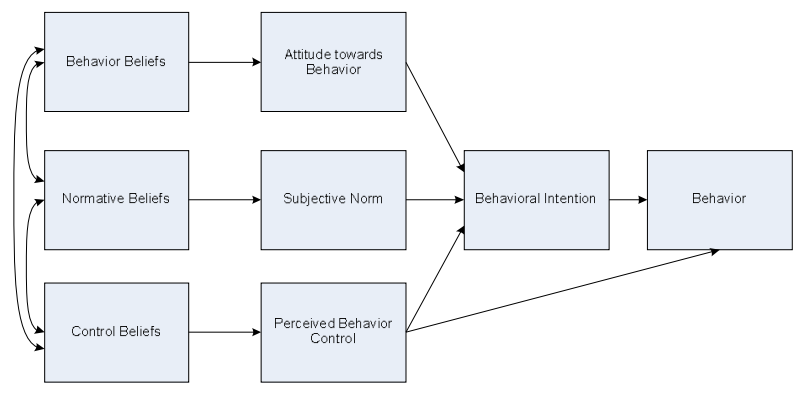

Gambar 2. Theory of Planned Behaviour (TPB)

(Ajzen, 1988)

\subsubsection{Theory Acceptance Model (TAM)}

TAM (Technology Acceptance Model) merupakan pengembangan dari TRA (Theory of Reasoned Action) oleh Davis et al.(1989) dalam Jogiyanto (2007) [8]. Model TRA dapat diterapkan karena keputusan yang dilakukan oleh individu untuk menerima suatu teknologi sistem informasi merupakan tindakan sadar yang dapat dijelaskan dan diprediksi oleh minat pelakunya (Jogiyanto, 2007) [8].

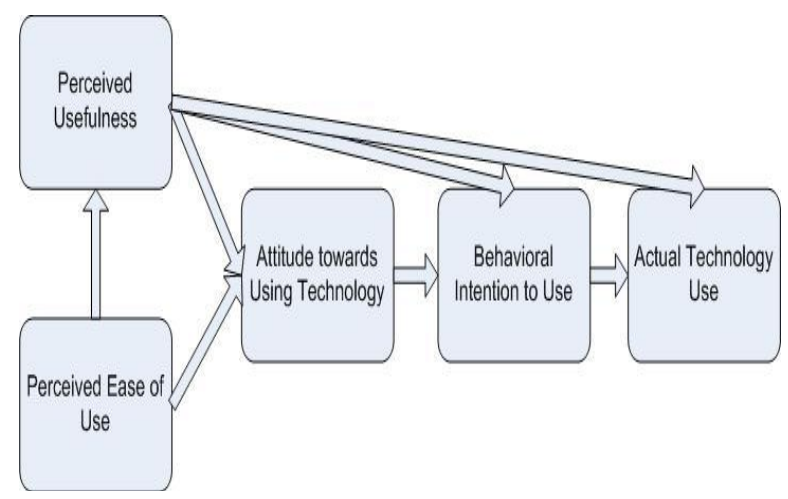

Gambar 3. Theory Acceptance Model (TAM)

(Davis et al., 1989) [10]

Berdasarkan gambar Theory Acceptance Model (TAM), persepsi kegunaan (perceived usefulness) dan persepsi kemudahan (perceived ease of use) mempunyai pengaruh ke minat perilaku (behavioral intention). Pengguna teknologi akan mempunyai minat menggunakan teknologi (minat perilaku) jika merasa sistem teknologi bermanfaat dan mudah digunakan.

Persepsi kegunaan (perceived usefulness) juga mempengaruhi persepsi kemudahan (perceived ease of use). Pengguna sistem akan menggunakan sistem jika sistem bermanfaat baik sistem itu mudah digunakan atau tidak mudah digunakan. Sistem yang sulit digunakan akan tetap digunakan jika pemakai merasa bahwa sistem masih berguna dalam pemanfaatannya.

\section{METODE PENELITIAN}

\subsection{Cara Pengambilan Sampel}

Penelitian ini dilakukan di UKM Kota Palembang, yaitu pada toko-toko komputer yang telah menggunakan penjualan Online. Populasi dalam penelitian ini adalah seluruh pengguna di empat toko komputer tersebut. Pengambilan sampel dilakukan secara acak sederhana dengan jumlah populasi sekitar 100 orang pengguna, diperkirakan jumlah sampel yang dibutuhkan 
mencapai sekitar 110 sampel. Hal ini didasarkan perhitungan jumlah sampel menggunakan pendekatan Solvin dengan margin of error sebesar 5\%.

\subsection{Cara Pengumpulan Data}

Data yang digunakan dalam penelitian ini adalah data primer. Kuesioner terdiri atas tiga bagian pertanyaan dimana setiap bagian pertanyaan mewakili sebuah variabel penelitian. Kuesioner menggunakan skala linked 1 sampai dengan 5 dengan ukuran dari angka terendah mempunyai arti sangat tidak setuju (STS) sampai angka tertinggi yang mempunyai arti sangat setuju (SS).

\subsection{Variabel Penelitian}

\subsubsection{Variabel Bebas}

Berdasarkan pada rancangan penelitian maka terdapat dua variabel bebas yakni perceived usefulness dan perceived ease of use. Perceived usefulness diartikan sebagai tingkat dimana seseorang percaya bahwa menggunakan sistem tertentu dapat meningkatkan kinerjanya dan perceived ease of use diartikan sebagai tingkat dimana seseorang percaya bahwa menggunakan sistem tidak diperlukan usaha apapun. Persepsi kegunaan (perceived usefulness) juga mempengaruhi persepsi kemudahan (perceived ease of use). Pengguna sistem akan menggunakan sistem jika sistem bermanfaat baik sistem itu mudah digunakan atau tidak mudah digunakan.

\subsubsection{Variabel Terikat}

Prestasi didefinisikan sebagai ukuran peningkatan dari perubahan sikap dan perilaku pengguna dalam menggunakan aplikasi E-Commerce.

\subsection{Analisis Data}

Cara analisis data pada penelitian ini menggunakan teknik analisis regresi linier berganda.

\section{HASIL DAN PEMBAHASAN}

\subsection{Data Penelitian}

Pada bab ini melakukan pengolahan data yang akan menentukan hasil dari penelitian tersebut. Pada penelitan ini jumlah kusioner yang dibagikan berjumlah 200 lembar. Dari jumlah kusioner yang disebarkan yang kembali berjumlah 180. Dengan keterangan15 hilang dan tak dikembalikan dan sisanya tidak dapat diolah karena rusak. Sebelum diolah lebih lanjut, data yang diperoleh melalui kuesioner terlebih dahulu dikodekan. Dengan asumsi setiap jawaban item pertanyaan diwakili oleh lima point skala linkert. Jawaban sangat setuju diwakili oleh angka 1, kurang setuju diwakili angka 2, netral diwakili angka 3, setuju diwakili angka 4 dan sangat setuju diwakili angka 5. Peneltian ini menggunakan dua variable $\mathrm{X}$ dan satu variabel $\mathrm{Y}$.

Tabel 1. Profil Responden

\begin{tabular}{|c|c|}
\hline ProfilResponden & Jumlah \\
\hline \multicolumn{2}{|l|}{ JenisKelamin } \\
\hline Laki-laki & 38 \\
\hline Perempuan & 68 \\
\hline Total & 180 \\
\hline
\end{tabular}




\subsection{UjiValiditas dan Reliabilitas}

\subsubsection{Uji Validitas}

Pada Uji Validitas digunakan untuk mengetahui kelayakan butir-butir dalam suatu daftar pertanyaan dalam mendefinisikan suatu variabel. Menurut Kuncoro (2003:231) [11] bahwa untuk menentukan validitas digunakan teknik korelasi product moment dengan bantuan perangkat lunak SPSS versi 17.0. Pengujian validitas variabel dengan software Statistical Product and Service Solutions (SPSS) Versi 17.0 nilai validitas terdapat pada kolom Corrected Item-Total Corelation. Uji signifikansi untuk melihat valid tidaknya data dapat dilakukan dengan membandingkan nilai $r$ hitung dengan t 98aria untuk degree of freedom $(\mathrm{df})=\mathrm{n}-\mathrm{k}$, dalam hal ini $\mathrm{n}$ adalah jumlah sampel dan $\mathrm{k}$ adalah jumlah konstruk. Jika $\mathrm{r}$ hitung (untuk $\mathrm{r}$ tiap butir data dilihat pada kolom Corrected Item-Total Correlation) lebih besar dari $r$ table dan nilai r positif, maka butir atau pertanyaan tersebut dinyatakan valid. Dari hasil pengujian didapat bahwa nilai corrected item-total correlation ( $\mathrm{r}$ hitung), semuanya lebih dari 0.1743 ( $\mathrm{r}$ tabel untuk jumlah sampel 125, jadi df = 123), sehingga dapat disimpulkan bahwa semua butir pernyataan tersebut valid.

\subsubsection{Uji Reliabilitas}

Uji Reliabilitas dilakukan untuk mengukur apakah instrumen yang digunakan benarbenar bebas dari kesalahan (error). Nilai koefisien Cronbach Alpha, Menurut Nunnaly dalam (Ghozali, 2007, h.46) [12], suatu konstruk atau variabel dapat dikatakan reliabel jika nilai Cronbach's Alpha > 0,6. Dari tabel 5.3 diatas, terlihat bahwa variabel memiliki nilai Cronbach's Alpha lebih besar dari 0,6 maka dapat disimpulkan bahwa variabel dalam penelitian ini adalah reliabel.

\subsection{Uji Normalitas}

Pengujian normalitas dan pendekatan data akan diasumsikan berdistribusi normal apabila signifikansi K-S Z > 0,05 (asymptotic significance). Hasil pengujian pada gambar 4. menunjukkan bahwa semua variabel penelitian terdistribusi normal yang ditunjukkan dengan nilai asymptotic significance untuk masing-masing variabel > 0,05

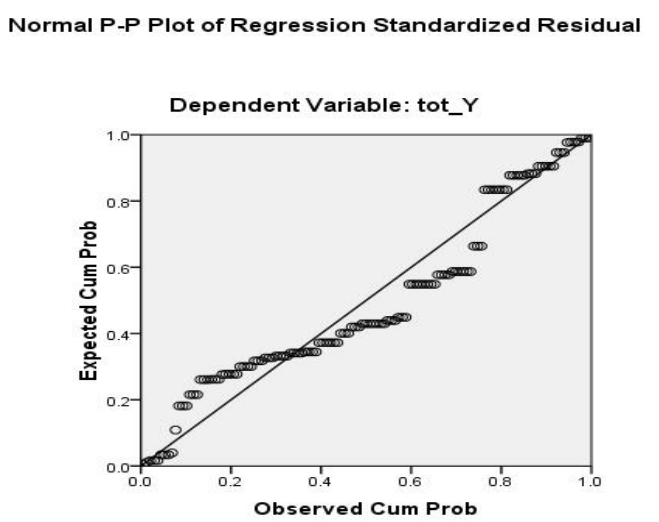

Gambar 4. Hasil Uji Normalitas

\subsection{UjiHeteroskedastisitas}

Heteroskedastisitas adalah situasi tidak konstannya varians. Uji Glesjer dilakukan dengan cara meregresi nilai absolut residual dari model yang diestimasi terhadap variabelvariabel bebas. Pengujian heteroskedastisitas di dalam penelitian ini dilakukan dengan cara melakukan regresi antara variabel independen dengan nilai residual absolut. Apabila variabel independen berpengaruh secara signifikan terhadap nilai residual absolut, maka terjadi heteroskedastisitas. 


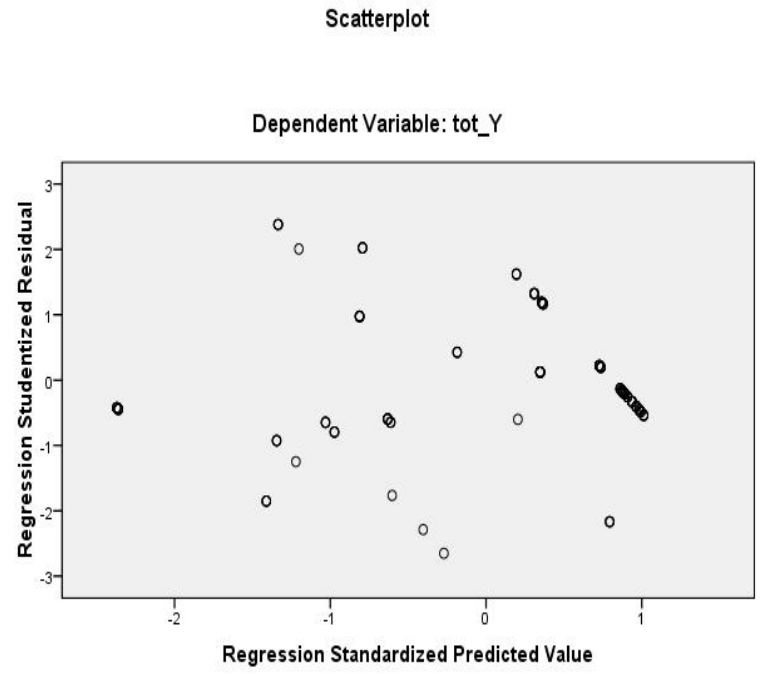

Gambar 5. Hasil Uji Heteroskedastisitas

Hasil pengujian heteroskedastisitas menunjukkan bahwa tidak ada variabel independen yang berpengaruh secara signifikan (nilai signifikan $<0,05$ ) terhadap nilai residual absolut. Dengan demikian dapat dikatakan bahwa tidak terjadi heteroskedastisitas. Berikutnya pengujian validitas, reliabilitas, dannormalitas yang telah dilakukan maka seluruh variabel dapat digunakan dalam penelitan yang berindikasi pada sahnya persamaan regresi.

\subsection{Hasil Uji Regresi Berganda}

Berdasarkan hasil pengujian hipotesis untuk uji regresi maka hasil regresi linear berganda maka dapat dibuat persamaan regresinya. Dari hasil tabel berikut ini tedapat hasil sebagai berikut:

Tabel 2. Hasil Analisis Regresi Berganda

\begin{tabular}{|c|c|c|c|}
\hline Persamaan Regresi & $\begin{array}{c}\text { Adjusted } \\
\mathbf{R}^{\mathbf{2}}\end{array}$ & $\begin{array}{c}\text { Nilai } \\
\mathbf{P}\end{array}$ & Kesimpulan \\
\hline $\mathrm{Y}=3.144+$ & 0,867 & 0,000 & Diterima \\
$0.382 \mathrm{X}_{1}+0.13 \mathrm{X}_{2}$ & & & \\
\hline
\end{tabular}

Didasarkan pada hasil perhitungan tabel diatas diperoleh angka signifikan sebesar 0,000, yang lebih kecil dari 0,05. Oleh karena itu $\mathrm{H}_{0}$ ditolak dan Hi diterima.

\section{KESIMPULAN}

Berdasarkan hasil analisis data dari pengujian empiris yang telah dilakukan oleh peneliti didapatkan bahwa:

1. Perceived Usefulness berpengaruh signifikan terhadap Pemanfaatan E-Commerce di UKM Kota Palembang. Artinya responden menganggap dengan menggunakan aplikasi E-Commerce tersebut mereka percaya bahwa dengan menggunakan sistem tersebut dapat membantu responden untuk mendapatkan keuntungan - keuntungan kienerja didalam pekerjaannya. (Jogiyanto : 2007) [8]

2. Perceived ease of use memberikan pengaruh yang signifikan atas Pemanfaatan ECommerce terhadap manfaat E-Commercetersebut. Pengaruh yang signifikan ini di 
Pengguna Palembang relatif mudah digunakan dan berdasarkan hasil wawancara singkat dengan responden diperoleh informasi bahwa sebagian besar responden telah memiliki keahlian/pengalaman menggunakan komputer.

3. Variabel Pemanfaatan E-Commerce Pengguna Palembang berpengaruh positif dan signifikan, sehingga dapat disimpulkan bahwa variabel Perceived Usefulness, Perceived ease of use terdukung dalam penelitian ini dapat menentukan manfaat dan efektivitas ECommerce di UKM Kota Palembang khususnya pada toko komputer.

\section{DAFTAR PUSTAKA}

[1] Molla, A. and Licker, P.S. 2001, E-Commerce Systems Success: An Attempt to Extend and Respecify the DeLone and McLean model of IS Success, Journal of Electronic Commerce Research

[2] Haag, S., Cummings, M., \& Dawkins, J. 1998, 'Management Information Systems for The Information Age', McGraw-Hill, USA

[3] Hoffman, D.L. \& Novak, T.H. 1997, 'A New Marketing Paradigm for Electronic Commerce', The Information Society, vol.13.

[4] Siregar, Riki R. 2010, "Strategi Meningkatkan Persaingan Bisnis Perusahaan dengan Penerapan E-Commerce". http://blog.trisakti.ac.id, Diakses tanggal 5 September 2017.

[5] Rahmati. 2009, Pemanfaatan E-Commerce Dalam Bisnis Di Indonesia, http://citozcome.blogspot.com/2009/05/pemanfaatan-e-commerce-dalambisnis-di.html, Diakses tanggal 4 September 2017

[6] Sarwono, Sarlito Wirawan, 1998, "Teori-teori Psikologi Sosial": Raja Grafindo Persada, Jakarta.

[7] Hidayat. 1986, Teori Efektifitas Dalam Kinerja Karyawan, Gajah Mada University Press, Yogyakarta.

[8] Hartono, Jogiyanto, 2007, Sistem Informasi Keperilakuan, Edisi Revisi, Andi, Yogyakarta.

[9] Ajzen, I., \& Fishbein, M., 1975, Belief, Attitude, Intention, and Behavior: An Introduction to Theory and Research, 129-385, Addison-Wesley, Reading, MA.

[10] Davis, F. D. 1989, Perceived Usefulness, Perceived Ease of Use, and User Acceptance of Information Technology, MIS Quarterly.

[11] Kuncoro, Mudrajad. 2003, Metode Riset untuk Bisnis, Erlangga, Jakarta.

[12] Ghozali, Imam. 2007, Analisis Multivariate Dengan Program SPSS, Cetakan Empat, Badan Penerbit Universitas Diponegoro, Semarang. 